\title{
Improvement of innovation ability of hospital managers and construction of competitive strategy
}

\author{
Li Han, \\ Weifang People's Hospital, \\ Weifang, Shandong 261000, \\ China \\ Jing Li, \\ The Affiliated Hospital of Qingdao University, \\ Qingdao, Shandong 266000, \\ China \\ Wenfeng Chen \\ Weifang People's Hospital, \\ Weifang, Shandong 261000, \\ China
}

Received: August 12, 2020. Revised: September 15, 2020. Accepted: October 28, 2020.

Published: November 3, 2020.

\begin{abstract}
At present, there are many problems in hospital management personnel, such as low quality of work and weak innovation ability, which are not conducive to the rapid development of hospitals. To effectively improve the innovation ability of hospital managers and establish a competitive strategy, this study took the head nurse of a hospital in Shandong province as the subject, determined the performance evaluation index through the review by authority, and established the reward and punishment system. It was found from the research results that only 36 people obtained three $A$ in the first month after the implementation of the performance management examination, and the number of people increased to 42 in the second third month. The results of the quarterly examination showed that the number of head nurses who obtained five $A$ and four $A$ has exceeded half of the total number of head nurses. The research demonstrates that the method proposed in this study can help improve the working ability of hospital managers, and this study makes some contributions to establishing hospital competitive strategy and improving the soft competitiveness of hospitals.
\end{abstract}

Keywords-Improvement, innovation ability, management staff, performance management, training and guidance.

\section{INTRODUCTION}

$\mathrm{T}$ HE development of economy promotes the reform of the social medical system. Hospitals need to change in the tide of reform and improve their ability to remain competitive in the market. In order to improve the work quality and innovation ability of hospital managers, in recent years, hospitals at all levels have introduced performance management systems, but because of the complexity of hospital itself, the performance management system has not been very perfect [1], and there are problems such as low service efficiency and high cost of human resources [2]. First of all, the work types of hospital managers are complex and various, which brings difficulties to the assessment of management work and is difficult to ensure the assessment's impartiality. Secondly, most of the indicators of management work are presented in the qualitative form such as work summary and leader evaluation [3], which is difficult to quantify, and the standard is too vague to be convincing. Thirdly, most hospitals lack independent performance assessment system. The current performance appraisal system of hospitals is mostly formalized and lacks unified planning and management, resulting in low objective value, insufficient support, and low executive power. Finally, hospitals lack the feedback module of performance appraisal, so that they are unable to get the status of the implementation of performance 
appraisal management system among hospital management personnel in time and the improvement aspect of the system. At present, there are many studies on the cultivation of hospital managers. Scholars in China and abroad have done some relevant researches. Through researching the management strategy of a public hospital in Wuhan, Yang [4] put forward to set up the quantitative indicators of each post based on job description, and use the informatization platform to evaluate the performance of hospital management staff. Huang et al. [5] proposed to make clear of the management staff positioning and career development, improve their management performance appraisal and incentive mechanism, strengthen the management training system, and introduce high-level management personnel. Singer et al. [6] found through research that team and group training of managers could enhance the cooperation and learning ability among managers and effectively improve managers' cognition of management work. Nasiripour et al. [7] designed a fivedimensional model of 187 components (i,e., knowledge, abilities, management skills, personality attributes and attitudes), which was verified through seeking expert advice and field testing. Through investigation, they made clear the influencing factors of the work of the management staff to formulate the training plan and enhance the hospital management ability. Rabbani et al. [8] proposed strengthening the management capacity of hospitals through a formal training program to ensure that there is enough trained personnel with high quality to provide high-quality hospital services. Janati et al. [9] studied evidence-based management. The questionnaire survey found that managers could provide available evidence for hospital decision-making and make the best decision in evidence-based decision-making based on hexagon evidence source. Soares et al. [10] used a multidimensional model based on data envelopment analysis to analyze the performance of 21 public hospitals in Brazil and found that seven hospitals achieved $100 \%$ efficiency and the average efficiency of all hospitals was $79 \%$. Kuhlmann et al. [11] conducted a study on hospital management in Russia. Through the investigation of 15 hospitals, it was found that the cooperation system in hospital management in Russia was weak, and there was a lack of horizontal information exchange. Then, they put forward a new hospital management method and established the accountability system for hospital personnel. This paper aims to build a hospital's competitive strategy from the perspective of performance management system and counseling and training. On the basis of ensuring the quality of work, the innovation ability of the management staff is cultivated and enhanced. The improvement of hospital management personnel's soft power will also greatly enhance the competitiveness of hospitals in the market.

\section{The COMPOSITION AND EXISTING PROBlems OF Hospital MANAGEMENT STAFF IN CHINA}

\section{A. The Composition of Hospital Management Staff}

The management staff of hospitals in China mainly consists of the following components: doctors and nurses who have been engaged in clinical work for many years but can not do well in administration and management work due to the lack of management background; students who have just graduated from university with a graduate degree in management major but lack experience due to the unfamiliarity of the operational procedure of the hospital; staff temporarily transferred from other departments; cadres who have been transferred from the army and need some time to adapt to the pace of the hospital.

Therefore, since they are unfamiliar with the knowledge in management and have little access to related learning and training opportunities, they are very likely to meet troubles and bottlenecks in work [12].

\section{B. Imperfect Incentive System}

Firstly, as the resources of the hospitals are tilted [13], the first-line departments receive more rewards and overtime pay than the management staff, resulting in the failure of the bonus in stimulating the management staff. Unlike medical staff, the administrative staff's promotion system is yet to be perfected. Despite of the fact that the work of them is complicated, the responsibility division is not clear. Taking the position of head nurse as an example, it covers the responsibilities of ensuring department health and safety, monitoring the work completion situation of nurses and equipment storage. However, the assessment on head nurses only considers a part of their work and can not fully reflect the work value and job responsibilities of head nurses. Therefore, we propose a competitive strategy to build a hospital with a perfect performance management system and a high input training program.

\section{IMPROVEMENT OF THE REWARD AND PUNISHMENT SYSTEM}

The cultivation of innovative ability is often based on the improvement of working ability and the optimization of knowledge structure. Therefore, this paper aims to help hospital managers determine the goal, improve the quality of work and lay a foundation for improving the innovation ability of managers from the perspective of perfecting the performance management system.

\section{A. Defects of the Current Performance Management System in Hospitals}

In recent years, hospitals in various levels have introduced the system of performance management, but because of the complexity of the hospital itself, the performance management system has not yet been perfect [14]. The defects of the current performance management system in hospitals mainly reflect in the following aspects.

(1) Hospital managers need to treat various categories of jobs. The job responsibilities are not clear; therefore, there are phenomena such as buckpassing and poor work enthusiasm.

(2) The indicators of management works are relatively simple. Most of the management works is presented by qualltative forms, such as work summary, leader assessment, etc. [15] The standard is too fuzzy, which can not be 
convincing.

(3) The current performance appraisal system is usually formalistic and lacks unified planning and management, leading to low objective value, insufficient support, and poor executive ability.

(4) Hospitals lacks the feedback module of the performance appraisal so that they can not know the implementation status of the performance appraisal management system in time and the aspects where the system needs to be improved. In the management process, delayed correction of wrong behaviors of management staff may make them attend the assessment for the purpose of completing tasks.

(5) The result of the performance assessment is not applied well in the management works of hospitals and is not integrated with the promotion and training of staff; therefore, the system cannot motivate the staff.

\section{B. Selection of Performance Indicators}

Based on the status of a top three hospital in Shandong Province, this paper selects performance indicators, puts forward some quantitative suggestions and specifies the performance management mechanism rules. Led by a dean, a party secretary,and three deputy deans, a Grade A hospital in Shandong has a total of 62 departments, including 22 functional departments, 32 clinical departments, and 8 medical technology departments. Every department has a head nurse. Clinical departments are divided into surgery departments with bed and clinical department without bed.

To establish an independent performance management system, a performance management office [16] should be set up, responsible for the evaluation of hospital management performance system and the implementation of work management as well as the inspection of the management work summary. Besides, a performance statistics and feedback team and feedback channel phone or email should be set up to facilitate the communication between hospital managers at all levels.

This paper takes the management position of the head nurse as an example and puts forward the corresponding performance management system, which is a reference for the performance management system of hospital administrators. In this study, 15 authoritative persons who had many years of experience in nursing management in Shandong Province were invited to discuss and determine the job performance indicators in the performance evaluation system according to the evaluation criteria of Grade A hospitals. The results are shown in table 1. The Nursing Department examined the work details of the head nurse's department and conducted the corresponding scoring on the individual performance standards of the head nurse according to the specific quality assessment standards and the suggestions of other managers in the department. The indexes of assessment mainly focus on the work content of the head nurse in every department and the basic knowledge mastered by the head nurse, and the details were further divided. On the one hand, it assessed whether the head nurse could do the management work in strict accordance with the management standards of its department; on the other hand, it assessed whether the head nurse had leadership and competency and whether they could correctly guide and train the nurses [17] to master the necessary skills, such as communication, etiquette, nursing, and health and safety assurance. Single performance appraisal can fully reflect the strengths and weaknesses of the management work of the head nurse.

Table 1 nursing management performance evaluation standards

\begin{tabular}{|c|c|c|c|}
\hline $\begin{array}{l}\text { Level } 1 \\
\text { indicator }\end{array}$ & Score & Details & $\begin{array}{l}\text { Performa } \\
\text { nce- } \\
\text { appraisal } \\
\text { cycle }\end{array}$ \\
\hline $\begin{array}{l}\text { Dialysis } \\
\text { room }\end{array}$ & 20 points & $\begin{array}{l}\text { 1. Implementation of } \\
\text { dialysis room care } \\
\text { quality assessment } \\
\text { standards ( } 6 \\
\text { points). } \\
\text { 2. Check whether } \\
\text { nurses' nursing } \\
\text { records are } \\
\text { normative (6 } \\
\text { points). } \\
\text { 3. Close } \\
\text { communication } \\
\text { with the nursing } \\
\text { department and } \\
\text { keep records ( } 4 \\
\text { points). } \\
\text { 4. Regular inspection } \\
\text { and maintenance } \\
\text { of machines and } \\
\text { water and } \\
\text { electricity in the } \\
\text { dialysis room ( } 4 \\
\text { points). }\end{array}$ & \multirow[t]{3}{*}{ Monthly } \\
\hline $\begin{array}{l}\text { Delivery } \\
\text { room }\end{array}$ & 20 points & $\begin{array}{l}\text { 1. Implementation of } \\
\text { delivery room nursing } \\
\text { quality management } \\
\text { assessment standards } \\
\text { ( } 10 \text { points). } \\
\text { 2. Explain the general } \\
\text { situation of maternal } \\
\text { labor to the puerpera } \\
\text { ( } 6 \text { points). } \\
3 . \text { Whether the } \\
\text { patient's transfer } \\
\text { record is } \\
\text { comprehensive ( } 4 \\
\text { points). }\end{array}$ & \\
\hline ICU & 20 points & $\begin{array}{l}\text { 1. Strict } \\
\text { implementation of } \\
\text { ICU nursing } \\
\text { quality } \\
\text { management } \\
\text { assessment } \\
\text { standards (6 }\end{array}$ & \\
\hline
\end{tabular}




\begin{tabular}{|c|c|c|c|c|c|c|}
\hline & & \multirow[b]{2}{*}{$\begin{array}{l}\text { points). } \\
\text { 2. A complete record } \\
\text { of transfer with the } \\
\text { clinical } \\
\text { department ( } 6 \\
\text { points). } \\
\text { 3. Implementation of } \\
\text { the use of various } \\
\text { identification } \\
\text { marks (4 points). } \\
\text { 4. Maintain good } \\
\text { communication } \\
\text { with doctors to } \\
\text { meet the needs of } \\
\text { clinical work and } \\
\text { inpatients ( } 4 \\
\text { points). }\end{array}$} & $\begin{array}{l}\text { behavior } \\
\text { etiquette }\end{array}$ & & $\begin{array}{l}\text { behavior etiquette meet } \\
\text { the standard ( } 20 \\
\text { points). }\end{array}$ & \multirow{7}{*}{$\begin{array}{c}\text { Seasonall } \\
\mathrm{y}\end{array}$} \\
\hline & & & $\begin{array}{l}\text { Basic care } \\
\text { and special } \\
\text { care }\end{array}$ & 20 points & $\begin{array}{l}\text { 1. Strict } \\
\text { implementation of } \\
\text { basic care quality } \\
\text { assessment } \\
\text { standards ( } 6 \\
\text { points). } \\
\text { 2. Strict } \\
\text { implementation of } \\
\text { special care } \\
\text { quality assessment } \\
\text { standards ( } 6 \\
\text { points). } \\
\text { 3. Grasp the total } \\
\text { number of patients }\end{array}$ & \\
\hline \multirow[t]{2}{*}{$\begin{array}{l}\text { Operating } \\
\text { room }\end{array}$} & \multirow[t]{2}{*}{20 points } & \multirow[t]{2}{*}{$\begin{array}{l}\text { 1. Strict } \\
\text { implementation of } \\
\text { the operating room } \\
\text { nursing quality } \\
\text { management } \\
\text { assessment } \\
\text { standards (10 } \\
\text { points). } \\
\text { 2. Timely pathological } \\
\text { specimen } \\
\text { submission for } \\
\text { inspection, shift } \\
\text { change in strict } \\
\text { accordance with } \\
\text { rules (4 points). } \\
\text { 3. Timely preoperative } \\
\text { and postoperative } \\
\text { visits, with a good } \\
\text { record (4 points). } \\
\text { 4. Timely clinical } \\
\text { communication } \\
\text { and regular } \\
\text { follow-up records } \\
\text { (2 points). }\end{array}$} & & & $\begin{array}{l}\text { in the treatment } \\
\text { area and the } \\
\text { specific number of } \\
\text { patients with mild } \\
\text { and severe } \\
\text { disease; for } \\
\text { critically ill and } \\
\text { primary care } \\
\text { patients, grasp } \\
\text { eight items: bed } \\
\text { number, name, } \\
\text { diagnosis result, } \\
\text { diet requirement, } \\
\text { treatment plan, } \\
\text { nursing } \\
\text { requirement, } \\
\text { disease condition, } \\
\text { mental status (4 } \\
\text { points). } \\
\text { 4. Serve medicines to } \\
\text { the mouth of the } \\
\text { patients (4 points). }\end{array}$ & \\
\hline & & & \multirow{2}{*}{$\begin{array}{l}\text { Ward } \\
\text { manageme } \\
\mathrm{nt}\end{array}$} & \multirow[t]{2}{*}{20 points } & $\begin{array}{l}\text { 1. Implementation of } \\
\text { ward quality }\end{array}$ & \\
\hline \multirow[t]{2}{*}{$\begin{array}{l}\text { Three base } \\
\text { training } \\
\text { (basic } \\
\text { theory, } \\
\text { basic } \\
\text { knowledge } \\
\text {, basic } \\
\text { skills) }\end{array}$} & \multirow[t]{2}{*}{20 points } & \multirow{2}{*}{$\begin{array}{l}\text { 1. Develop a training } \\
\text { plan according to } \\
\text { the characteristics } \\
\text { of the department } \\
\text { (10 points). } \\
\text { 2. Lecturing according } \\
\text { to plan } \\
\text { comprehensively } \\
\text { and nurses have } \\
\text { study notes ( } 6 \\
\text { points). } \\
\text { 3. Training nursing } \\
\text { skills of the nurses } \\
\text { to a proficiency } \\
\text { level (4 points). }\end{array}$} & & & $\begin{array}{l}\text { management } \\
\text { standards ( } 10 \\
\text { points). } \\
\text { 2. Develop and } \\
\text { implement weekly } \\
\text { and monthly } \\
\text { management plans } \\
\text { (10 points). }\end{array}$ & \\
\hline & & & \multirow[t]{2}{*}{$\begin{array}{l}\text { Nursing } \\
\text { safety }\end{array}$} & \multirow[t]{2}{*}{20 points } & \multirow[t]{2}{*}{$\begin{array}{l}\text { 1. Implementation of } \\
\text { quality } \\
\text { management } \\
\text { standards for } \\
\text { nursing safety ( } 8 \\
\text { points). } \\
\text { 2. Timely reporting } \\
\text { and handling of }\end{array}$} & \\
\hline Nurse & 20 points & Nurses' dress up and & & & & \\
\hline
\end{tabular}




\begin{tabular}{|c|c|c|}
\hline & & $\begin{array}{l}\text { hidden dangers } \\
\text { and adverse events } \\
\text { ( } 4 \text { points). } \\
\text { 3. Handover and risk } \\
\text { records meet the } \\
\text { standards ( } 4 \\
\text { points). } \\
\text { 4. Implementation of } \\
\text { the use of various } \\
\text { identification } \\
\text { marks ( } 4 \text { points). }\end{array}$ \\
\hline $\begin{array}{l}\text { Health } \\
\text { education }\end{array}$ & 20 points & $\begin{array}{l}\text { 1. Inform the patient of } \\
\text { the name of his } \\
\text { managing doctor } \\
\text { and responsible } \\
\text { nurse ( } 6 \text { points). } \\
\text { 2. Inform the patient of } \\
\text { their condition, } \\
\text { diet requirement, } \\
\text { medication, and } \\
\text { precautions ( } 8 \\
\text { points). } \\
\text { 3. Guide the patient to } \\
\text { acquire health } \\
\text { rehabilitation } \\
\text { knowledge ( } 6 \\
\text { points). }\end{array}$ \\
\hline
\end{tabular}

C. Performance Management Communication and Feedback

Before beginning to implement the performance management system, the senior management staff of the hospital should first develop a performance management plan. The plan includes the set objectives, implementation principles and incentives and is told to the middle and grassroot management staff to help them determine their work objectives. Also, communication should be strengthened and the suggestions of the middle and grassroot management staff on the plan should be adopted, which is beneficial to the efficient implementation of the performance management system in the hospital.

Performance feedback [18] is an important link in the performance management system. The hospital should improve the feedback mechanism and strengthen the communication between the management staff and examiners. While affirming the achievements of the management staff, it is also important to explore the deficiencies of the system and make improvement. The performance feedback should be carried out on a regular basis, i.e., monthly or seasonally, which is beneficial for hospitals to find out the problems of the performance system in time.

\section{Application of Performance Appraisal Results}

The final score of the head nurse's performance indicators is classified into three categories of A, B and C. A: 95 or more points; B: 85 to 95 points; C: 85 points or less. If a head nurse has eight or more job performance indicators rated as Grade A, her overall performance appraisal is excellent; if a head nurse has eight job performance indicators rated as Grade $\mathrm{C}$, her overall performance appraisal is poor.

Focusing on improving managers' ability to innovate, it is important, first and foremost, to foster high-quality managerial staff. For those nurses rated as excellent, the hospital should enhance their wage levels and the basic level of posts as incentives. For those rated as poor, the hospital should deduct their bonuses, reduce the basic level of posts and arrange them to carry out relevant training.

On the other hand, the hospital should encourage the excellent head nurses to communicate with other head nurses [19] to summarize experience and put forward new management suggestions to improve the level of overall management of the head nurses of the hospital.

\section{E. Reward and punishment system}

The head nurse department performance indicators and single performance indicators were classified into three categories, A, B and C, A for 95 or more points, B for $85 \sim 95$ points, and $\mathrm{C}$ for 85 points or less. Statistics performed every quarter. Statistical results include three monthly assessments (single performance appraisal) and two quarterly assessments (single performance appraisal and department performance appraisal). In a quarterly assessment, the maximum number of A that every nurse head could get was five.

The head nurse's pose basis was set as eight posts and 24 levels, and the salary was between 2500 and 4200. Different post basis corresponded to different salaries.

The hospital performance management office sorted the personal performance files. For head nurses with four or more Level $\mathrm{A}$ in a quarter, their position improved for one level; for head nurses with four or more Level $\mathrm{C}$ in a quarter, their position reduced for one level. The office of Performance Management reported the list to the Performance Management Committee, and then the list was forwarded to the Human Resources Department for implementation.

\section{RESULTS}

Sixty-two head nurses in the hospital were assessed using the performance management system designed in this study, including three monthly assessments and one quarterly assessment, in July 2017, August 2017, September 2017, and the third quarter of 2017. The assessment results are shown below. 


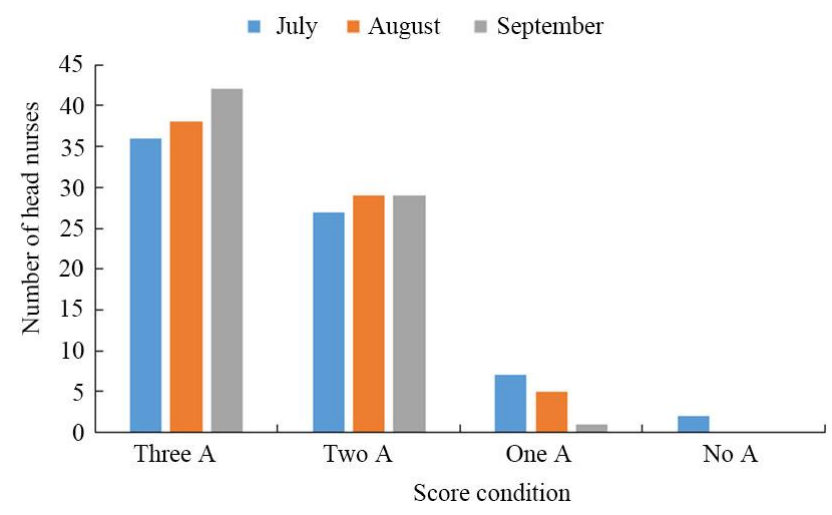

Fig. 1 The monthly assessment results

Fig. 1 shows the change of head nurses' scores in the three months since the implementation of the performance management system. It was seen from Fig. 1 that 36 head nurses got three A, 6 head nurses got one A, and 2 head nurses got no $\mathrm{A}$ in the monthly assessment in the first month, i.e., July. In the first month, the assessment of head nurses was not good. Then in August, the number of head nurses who got two or three A increased, while the number of head nurses who got one A or no A decreased. In the third month, i.e., September, the number of head nurses who got three $\mathrm{A}$ was 42 , the number of head nurses who got two A was 29, and only one had one A. It showed that the working ability of head nurses significantly improved under the incentive of the performance management system.

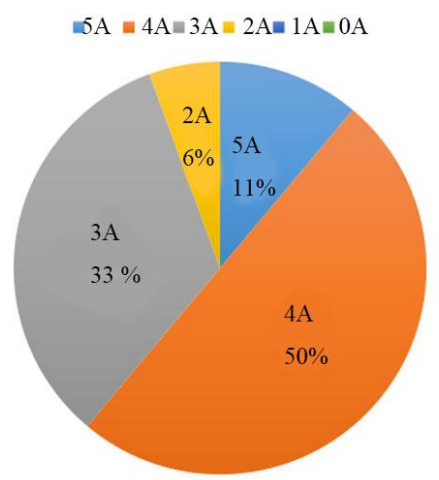

Fig. 2 The quarterly assessment results

Fig. 2 shows the comprehensive assessment result of the third quarter in 2017. It was found that the number of head nurses who got $5 \mathrm{~A}$ and $4 \mathrm{~A}$ has exceeded half of the total number, indicating that the performance management system designed in this study was effective and could effectively urge head nurses to improve their working ability and strictly follow hospital rules and regulations to strengthen the soft power of the hospital.

\section{DISCUSSION}

To improve the innovation ability of hospital managers and establish a competitive strategy, this study analyzed the performance management of head nurses in hospitals, established the corresponding index system, and evaluated the work of head nurses. It was found from the results that the working ability of head nurses has been significantly improved under the performance management system designed in this paper. First of all, the results of monthly assessment showed that the number of head nurses who got three A increased from 36 in the first month to 42 in the third month under the incentive of performance management. In the third month, only one head nurse got one A. Then, according to the results of the quarterly assessment, the number of head nurses with five A and four A was more than half of the total number. These results showed that the performance management system established in this paper was effective to improve the working ability of head nurses.

According to the research results of this paper, the following suggestions are put forward to improve the working ability and innovation ability of managers.

(1) Strengthen training and guidance. According to the situation and needs of hospital personnel, the hospital should increase the investment in [20] training, improve the management quality of hospital management personnel [21], teach the staff according to their aptitude, adopt the training methods of special training and full staff training, and carry out training through various modes, such as further study, academic exchange, cooperation with other hospitals, mutual observation and learning. The training should be divided into two modes. One is to provide training and guidance in relevant aspects for some managers whose performance evaluation is not up to the standard. For example, a head nurse got $\mathrm{C}$ in the performance assessment of health education knowledge, which may be due to poor communication skills and insufficient health rehabilitation knowledge; in such a case, the hospital should arrange relevant training and guidance. The other is aimed at the managers whose working ability is up to standard and whose working ability is outstanding. The training content should also be divided into two types: one is about the improvement of management ability, such as hospital standardized management, time management, medical quality management [22], etc.; the other is related to scientific research and academic innovation, such as information management, advanced management concept, hospital culture, and innovation consciousness.

(2) Reform the management system. According to the principle of fairness and openness, the hospital should select young managers who are familiar with business, have both ability and political integrity, and have innovative ability. They should establish the concept of attaching more importance to ability than education background and more importance to morality than talent, so that the managers can face difficulties, accept hardships, and experience setbacks in their actual work to cultivate their sense of innovation and creativity.

\section{CONCLUSION}

In view of the lack of relevant knowledge of hospital 
managers and the imperfect competition strategy, this study constructed a performance management and reward and punishment system for hospital managers. Taking the head nurse post of a hospital in Shandong Province as a case, this study verified through the analysis of monthly and quarterly assessment results of head nurses that the established system could improve the management ability of head nurses. The system is conducive to enhance the soft power of hospital internal management and improve the market competitiveness.

\section{REFERENCES}

[1] T. Gao and B. Gurd, "Meeting the challenge in performance management: the diffusion and implementation of the balanced scorecard in Chinese hospitals," Health Policy Plan., vol. 30, no. 2, pp. 234-241, 2015.

[2] L. Yi, A. Hao, M. Hu, P. Huang, H. Yuan, and M. Xing "Construction and Application of a Refined Hospital Management Chain," Cell Biochem. Biophys., vol. 72, no. 1, pp. 19-22, 2015.

[3] P. Zhou, K. Bundorf, J. Chang, J. X. Huang, and D. Xue, "Organizational culture and its relationship with hospital performance in public hospitals in China," Health Serv. Res., vol. 46, no. 6pt2, pp. 2139-2160, 2011.

[4] S. R. Yang, Y. Zhang, H. B. Wang, and H. B. Long, "Practice and Reflection on Performance Appraisal of Administration Stuff in a Public Hospital in Wuhan Based on 360-Degree-Feedback Appraisal," Med. Soc., no. 7, pp. 42-44, 2017.

[5] X. Y. Huang, L. M. Zhou, L. Li, W. D. Zhong, W. Z. Huang, and A. G. $\mathrm{Xu}$, "Present Situations :of Administrators rofessionalization in Guangzhou Public Hospital," Mod. Hospit., no. 9, pp. 1289-1291, 2017.

[6] S. J. Singer, J. Hayes, J. B. Cooper, et al., "A case for safety leadership team training of hospital managers," Health Care Manag. Rev., vol. 36, no. 2, pp. 188, 2011.

[7] P. Raeissi, and A. A. Nasiripour, "Management development in health care setting: a training model for hospital managers," J. Res. Health Sci., vol. 7, no. 2, pp. 42, 2011.

[8] F. Rabbani, F. N. Hashmani, A. A. A. Mukhi, X. Gulp, N. Pradhan, P. Hatcher, M. Farag, and F. Abbas "Hospital management training for the Eastern Mediterranean Region: time for a change?," Journal of Health Organization \& Management, vol. 29, no. 7, pp. 965-972, 2015.

[9] A. Janati, E. Hasanpoor, S. Hajebrahimi, and H. Sadeghi-Bazargani, "Health care managers' perspectives on the sources of evidence in evidence-based hospital management: A qualitative study in Iran," Ethiop. J. Health Sci., vol. 27, no. 6, pp. 659-, 2017.

[10] A. B. Soares, A. A. Pereira, and S. T. Milagre, "A model for multidimensional efficiency analysis of public hospital management," Res. Biomed. Eng., vol. 33, no. 4, pp. 352-361, 2017.

[11] E. Kuhlmann, S. Shishkin, E. Richardson, I. Ivanov, O. Shvabskii, I. Minulin, A. Shcheblykina, A. Kontsevaya, K. Bates, and M. McKee, "Hospital management in the Russian Federation: the role to physicians in the new models of management," Eur. J. Public Health, no. suppl_4, 2018.

[12] Z. G. Liu, and H. B. Yang, "The Characteristics and Implementation Strategy of Modern Hospital Knowledge Management. Business, Economics, Financial Sciences, and Management," Springer Berlin Heidelberg, vol. 117-121, 2012.

[13] Y. J. Moon, J. S. Park, and I. W. Ahn, "Investigation on the Management Status of Incentive Pay System in Hospital and Strategy to Invigorate," J Alloy. Compd., vol. 5, no. 1, pp. 77-82, 2011.

[14] T. Gao, and B. Gurd, "Meeting the challenge in performance management: the diffusion and implementation of the balanced scorecard in Chinese hospitals," Health Policy Plann., vol. 30, no. 2, pp. 234, 2015.

[15] P. Zhou, K. Bundorf, C. J. Le, et al., "Organizational culture and its relationship with hospital performance in public hospitals in China," Health Serv. Res., vol. 46, no. 6pt2, pp. 2139-2160, 2011.

[16] S. Spalek, "Improving Industrial Engineering Performance Through a Successful Project Management Office," Inz. Ekon.-Eng. Econ., vol. 24, no. 2, pp. 88-98, 2013.
[17] J. L. dos Santos, A. G. Prochnow, S. B. de Lima, J. L. Leite, and A. L. Erdmann, "Communication conceptions in hospital nursing management between head nurses in a university hospital," Rev. Esc. Enferm. Usp, vol. 45, no. 4, pp. 959-65,2011.

[18] M. C. Campion, E. D. Campion, and M. A. Campion, "Improvements in Performance Management Through the Use of 360 Feedback," Ind. Organ. Psychol., vol. 8, no. 1, pp. 85-93, 2015.

[19] S. Lehmann, A. D. Jackson, and B. E. Lautrup, "A quantitative analysis of indicators of scientific performance," Scientometrics, vol. 76, no. 2, pp. 369-390, 2017.

[20] H. S. Lee, "Knowledge Management Enablers and Process in Hospital Organizations," vol. 8, no. 1, pp. 26-33, 2017.

[21] C. Thim, and N. Weber, "Management Of Tacit Knowledge To Overcome Learning Barriers Between Professions," Eur. Conf. Knowledge Manag., vol. 1163-1171, 2012.

[22] B. Bolzan, and A. Galina, "Strategic Administraction and the Managerial Competences in the Administrative Structure of the Organizations," Heart, vol. 100, no. 13, pp. 1031-1036, 2014.

Li Han, born in 1984, has gained the master's degree from Huazhong University of Science and Technology in 2009. She is an economist. She is interested in hospital management.

Jin Li, born in 1984, has gained the master's degree from Qingdao University in 2010. She is an economist. She is interested in hospital management.

Wenfeng Chen, born in 1967, graduated from Weifang Medical University in 2003. She is co-chief superintendent nurse. She is interested in hospital management.

\section{Creative Commons Attribution License 4.0 (Attribution 4.0 International, CC BY 4.0)}

This article is published under the terms of the Creative Commons Attribution License 4.0 https://creativecommons.org/licenses/by/4.0/deed.en US 